Click www.researchjournal.co.in/online/subdetail.html to purchase.

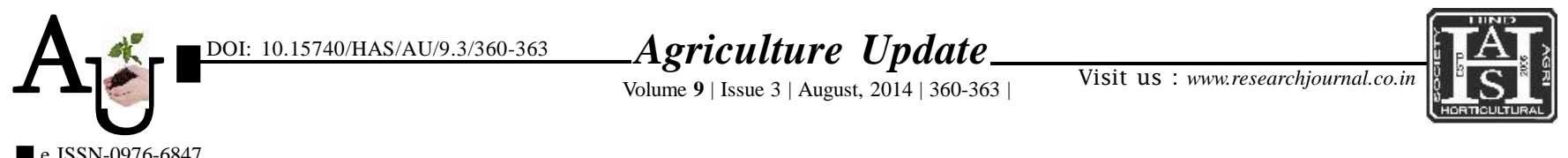

Research Article

\title{
Relationship between socio-economic characteristics and entrepreneurial behaviour of pomegranate growers
}

NAGESH AND S.V. HALAKATTI

Article Chronicle: Summary : A study on entrepreneurial behaviour of pomegranate growing farmers in Bagalkot district of Received :

19.08.2013;

Revised :

15.06.2014;

Accepted :

30.06.2014

Karnataka was carried out to analyze the pomegranate growers' entrepreneurship behaviour. The study revealed that majority of the farmers had medium entrepreneurial behaviour. Further the variables viz., education, land holding, annual family income, mass media participation, extension participation and scientific orientation showed significant relationship, while remaining variables viz., age, occupation and extension contact showed non-significant relationship with entrepreneurial behaviour of pomegranate farmers.

How to cite this article : Nagesh and Halakatti, S.V. (2014). Relationship between socio-economic characteristics and entrepreneurial behaviour of pomegranate growers. Agric. Update, 9(3): 360-363.

\section{KeY Words :}

Pomeganate farmers,

Entrepreneurial

behaviour, Socio-

economic characters

\section{NAGESH}

Department of Agricultural

Extension Education,

College of Agriculture,

University of Agricultural

Sciences, RAICHUR

(KARNATAKA) INDIA

Email: samarth.nagesh

@ gmail.com

See end of the article for

authors' affiliations 